Karla L. Hahn

\title{
Two new policies widen the path to balanced copyright management Developments on author rights
}

A light bulb is going off that is casting the issue of author rights management into new relief. On January 11, 2008, the National Institutes of Health (NIH) announced a revision of its Public Access Policy. Effective April 7, 2008, the agency requires investigators to deposit their articles stemming from NIH funding in the NIH online archive, PubMed Central. Librarians have been looking forward to such an announcement, especially since studies found that the voluntary version of the policy was achieving deposit rates of affected articles on the order of a few percentage points, making it impossible to achieve the policy's goals for broadening access to funded research and accelerating the pace of research advance. ${ }^{1}$

The shift from a request to a requirement comes at a propitious time; academic libraries already have been building infrastructure to work with faculty on both rights management and repository deposit. Author rights management has been the most common focus of faculty outreach on campuses in recent years. ${ }^{2}$ The value of digital repositories and preprint and postprint deposit has also been broadly communicated. The revised policy thus has not only found a hospitable environment, but it also has effectively catalyzed ongoing discussions about the obligations of scholars and researchers not merely to publish, but to act to achieve the broadest possible dissemination of their findings.

With opportunity, of course, comes responsibility. It is now apparent that many leaders on campus, and many faculty, still faced a learning curve as they prepared for the change in the policy. On many campuses, librarians have been in a position to exercise leadership by reaching out to key stakeholders, particularly campus research offices, and clarifying the implications of the revisions to the policy and enabling the rapid development of compliance strategies. In the short term, libraries have built new and very positive relationships on campus as a result of their contributions in support of grantees and investigators' meeting the policy's requirements.

Libraries have contributed to the success of the policy by creating resources, fostering the creation of campus tools, and using and promoting resources developed by library associations (see sidebar). As the librarian community has understood from the outset, one of the key transformations the policy initiates is a shift in researchers' management of their copyrights of the works they author. With the article deposit requirement, researchers can no longer simply sign publication agreements without careful review and, in some cases, modification of the publisher's proposed terms. While this may be perceived as a minor annoyance, it calls attention to the value of scholarly publications and the necessity to consider carefully whether an appropriate

Contact Joyce L. Ogburn—series editor, cochair of the ACRL Scholarly Communications Committee, and university librarian at the University of Utah-with article ideas, e-mail: joyce.ogburn@utah.edu

Karla L. Hahn is director of the Office of Scholarly Communications at the Association of Research Libraries, e-mail: karla@arl.org

c 2008 Karla L. Hahn 
balance between author and publisher rights and needs is on offer.

As institutions, as grantees, become responsible for ensuring that funded authors retain the rights they need to meet the NIH public Access Policy requirements, there is a new incentive for campus leaders to reconsider institutional policies and local practices relating to faculty copyrights as assets. ${ }^{3}$

In 2000, the "Tempe Principles for Emerging Systems of Scholarly Publishing" promulgated by library and campus leaders, included two statements regarding rights management:

The academic community embraces the concepts of copyright and fair use and seeks a balance in the interest of owners and users in the digital environment. Universities, colleges, and especially their faculties should manage copyright and its limitations and exceptions in a manner that assures the faculty access to and use of their own published works in their research and teaching.

and

In negotiating publishing agreements, faculty should assign the rights to their work in a manner that promotes the ready use of their work and choose journals that support the goal of making scholarly publications available at reasonable cost. ${ }^{4}$
The requirements of the current NIH Public Access Policy mark substantial progress in implementing these principles and demonstrate the prescience of these statements.

The February 2008 vote by the Harvard Faculty of Arts and Sciences to grant Harvard a limited license to make certain uses of their journal articles is another important indicator of an accelerating shift in attitudes about author rights management, and also reveals the value of taking an institutional approach to the issue. At the heart of the policy is the idea that faculty and institutions should have more control over how work is used and disseminated, and that they have responsibility to distribute their scholarship as widely as possible. The Harvard Law faculty followed suit in the spring. ${ }^{5}$

With these two watershed developments, libraries have a new opportunity to educate and advocate for the development of a new generation of institutional policies on author rights management, one geared to the opportunities of networked digital technologies and built on the foundations of recent developments in rights management tools and institutional and disciplinary repositories. For librarians considering how best to help campus authors promote a healthy culture of copyright on campus-one that promotes research, teaching, learning, and service to society-a recent SPARC/Science Commons white paper, "Open Doors and Open Minds: What Faculty Authors Can Do to Ensure

\section{Resources for institutional author rights policy management approaches}

- SPARC: www.arl.org/sparc/advocacy/nih/index.shtml

- NIH Public Access Policy: Guide for Research Universities: www.arl.org/sc /implement/nih/guide/index.shtml

- Webcast Archive: Institutional Compliance with the NIH Public Access Policy: www.arl.org/sc/implement/nih/webcast /index.shtml

- Complying with the National Institutes of Health Public Access Policy: Copyright Considerations and Options: www.arl.org/sparc advocacy/nih/copyright.shtml
- Managing Copyright for NIH Public Access: Strategies to Ensure Compliance: www.arl.org/resources/pubs/br/br258. shtml

- Open Doors and Open Minds: What Faculty Authors Can Do To Ensure Open Access To Their Work Through Their Institution: www.arl.org /sparc/publications/guides/opendoors _v1.shtml

- Office for Scholarly Communication, Harvard University Library: hul.harvard. edu/osc.html 
Open Access to Their Work Through Their Institution," discusses several action strategies promoting the development of institutional policies. $^{6}$

Norms are always more difficult to change than technologies. We are now witnessing a key shift in norms for sharing scholarly work that promises a giant step forward in leveraging the potential of network technologies and digital scholarship to advance research, teaching, policy development, professional practice, and technology transfer. Librarians need to seek and promote today's burgeoning opportunities to accelerate these positive changes toward openness. The next important strategy to pursue is developing institutional policies that ensure institutions receive limited distribution rights.

\section{Notes}

1. Ray English and Heather Joseph, "The NIH mandate: An open access landmark." CERL News, Vol. 69, No. 2. February 2008, www.acrl.org/ala/acrl/acrlpubs/crlnews /backissues2008/february08/nihupdate.cfm

2. Kathleen A. Newman, Deborah D. Blecic, and Kimberly L. Armstrong, "Scholarly Communication Education Initiatives," SPEC Kit 299. Washington, D.C.: Association of Re- search Libraries (2007), www.arl.org/bm doc /spec299book.pdf.zip (accessed May 2008).

3. Michael Carroll, "Complying with the National Institutes of Health Public Access Policy: Copyright Considerations and Options" (February 2008), www.arl.org/sparc /advocacy/nih/copyright.html (accessed May 2008); and Kevin L. Smith, "Managing Copyright for NIH Public Access," ARL: A Bimonthly Report. no. 258 (June 2008), www. arl.org/resources/pubs/br/br258.shtml (accessed May 2008).

4. Tempe Principles for Emerging Systems of Scholarly Publishing available at www.arl.org /bm doc/tempe1.pdf (accessed May 2008).

5. "Harvard To Collect, Disseminate Scholarly Articles For Faculty," www.fas.harvard. edu/home/news_and_events/releases /scholarly_02122008.html (accessed June 2008); and "Harvard Law Faculty Votes for 'Open Access"” to Scholarly Articles," www.law.harvard.edu/news/2008/05/07 _openaccess.php (accessed June 2008).

6. Thinh Nguyen, "Open Doors and Open Minds: What faculty authors can do to ensure open access to their work through their institution" (April 2008), www.arl.org/sparc /publications/guides/opendoors_v1.shtml (accessed May 2008). n

\section{("A different kind of fellowship" continued from page 394)}

during the implementation of the fellowship program. These include teaching proper interview skills, communicating what is required of the fellow's supervisors, and making professional mentoring available. The task force has discussed these concerns with both the current SPA fellow and other library faculty and staff, and will take measures to provide future fellows and fellowship applicants with the needed advice and assistance.

Despite these challenges, everyone involved in the process agrees that the SPA Fellowship Program is a worthwhile endeavor that holds enormous promise for both support staff wishing to transition to professional librarianship and Joyner Library as an institution. Obviously it is still too early to tell if the program is successful. The ultimate test will come once we have library fellows who have completed the program and pursue full-time professional positions. That is when we will find out if the program is truly working as we intended. At this point, the feedback from both the inaugural library fellow and her co-workers and supervisors has been overwhelmingly positive. While there are still lessons to be learned and issues to be addressed, the fellowship program has worked out well so far and will certainly be continued.

\section{Notes}

1. For information on the NCSU Libraries Fellows Program, see www.lib.ncsu.edu /fellows/.

2. Available atwww.ecu.edu/cs-lib/SPA /Fellow_Com/Index.cfm. n 